\title{
Assessing the social factors of place dependence and changes in land use in sustainable agriculture: Case of Pandaan District, Pasuruan Regency, Indonesia
}

\author{
Gunawan Prayitno*, Wara Indira Rukmi and Muhammad Iqbal Ashari \\ Brawijaya University, Malang, Indonesia \\ *Correspondence email: gunawan_p@ub.ac.id
}

\section{ARTICLE INFO}

- Research Article

\section{Article History}

Received 12 November 2020

Accepted 14 January 2021

Published 1 April 2021

\section{Keywords}

environmental quality; landuse change; place dependence; sustainable agriculture

\section{JEL Classification}

R11; R52; Q15

\begin{abstract}
Times have led to changes in land functions and changes in environmental psychology's social, economic, and environmental aspects. Within Pandaan subdistrict, there is a main road linking Surabaya and Malang to the road hierarchy as a national arterial road, and the Gempol-Pandaan toll road has changed the function of agricultural land, particularly in Durensewu and Plintah Village. This study aims to determine the land conversion that occurs in the Pandaan District by knowing the place dependence and the relationship between the place dependence and the residents' decision to change land use. The analytical method used is the analysis of land-use change, the analysis of place dependence, and the relationship between place dependence and land-use change. Based on the results of the analysis, it is known that there is an indirect and positive relationship between place dependence and land-use change in the Pandaan District and that one of the dimensions of place dependence is environmental quality. The decision to change the land is connected to sustainable agriculture.
\end{abstract}

To cite this article: Prayitno, G., Rukmi, W. I. \& Ashari, M. I. (2021). Assessing the social factors of place dependence with changes in land use in sustainable agriculture: Case of Pandaan District, Pasuruan Regency, Indonesia. Journal of Socioeconomics and Development, 4(1), 8-20. https://doi.org/10.31328/jsed.v4i1.1720

ISSN 2615-6075 online; ISSN 2615-6946 print (c)WG Press, 2021

\section{INTRODUCTION}

The growing demand for land along with a rise in population affect land use (Siciliano, 2012). Pandaan District had a population of 117,556 in 2019 , higher than the previous year's 106,368 , or an increase of 11,118 people (BPS, 2020). This led to the increasing demand for land in the Pandaan District due to population growth. Apart from it, land demands have increased due to economic and social developments, as well as rising needs for settlements and infrastructure to reduce the disparity (Nugraha et al., 2020). It would lead to changes in land use (Siciliano, 2012), government land-use policy, economic condition and urbanization (Lambin \& Meyfroidt, 2010; Long \& Qu, 2018; Wang et al., 2018), food need (Foley et al., 2005), natural resources management (Purnomo et al., 2018) and relationship rural-urban (Romagosa et al., 2013). Besides, Boron et al. (2016) and Zeho et al. (2020) developed strategies to balance agricultural expansion with the conservation of biodiversity, rural growth; and rural development

Pasuruan Regency, which is situated in the province of East Java, is one of the regions where the land is predominantly used for agriculture, comprising 60 percent of the whole area of Pasuruan 
Regency. However, this figure continues to decline due to the transfer of land functions from the agricultural to the non-agricultural land use. The District of Pandaan is part of one of the districts with changed agricultural land's purpose (Prayitno et al., 2020). The decision of landowners to adjust their land's function reached 34\% (Prayitno et al., 2019). Areas with modified land functions in Pasuruan Regency are Durensewu Village and Plintah Village (Bappeda Kabupaten Pasuruan, 2010). Preliminary study showed that the people of those villages agreed to sell the land because of the high offer price, allowing the land to be used for the construction of formal housing. The decision to change land is a factor that influences changes in land use (Prayitno et al., 2018).

Times have led to changes in land function, which are related to changes in environmental psychology's social, economic, and environmental aspects. One of the theories in environmental psychology is place attachment. There are four dimensions that are part of the mechanism of creating place attachment, i.e. place identification, place dependency, place discovered, and place inherited (Verburq et al., 2015; Walker \& Ryan, 2008). Place dependence is a fastgrowing dimension dependent on these four dimensions (Trabka, 2019). It is also a practical commitment to a place that meets people's services and needs (Anton \& Lawrence, 2016). Dependence of place can be defined when people feel secure living and working in a place (Trabka, 2019). In achieving its objectives, the population is affected by five factors, namely land ownership, environmental quality, jobs, accessibility, and career development (Baldwin et al., 2017; Haryani et al., 2019; Lai \& Kreuter, 2012; Prayitno et al., 2019, 2020; Trabka, 2019).

The Pandaan District is crossed by a main road connecting Surabaya and Malang with the hierarchy as a national arterial road as well as the GempolPandaan Toll Road launched in 2014. This main road section in the Pandaan District was expected make it easier for the population to support their activities and meet their daily needs (Trabka, 2019). The preliminary survey in 2019 showed that Pandaan District people meet their regular needs by purchasing finished or raw materials. Based on the research by Rusmi (2019), the average of population expenditure on fulfilling their needs does not surpass the income received. The expense of residents is 0.5
- 1.5 million rupiah, with revenue from 1.0 million 2.0 million rupiahs. This shows that the income of the residents of the Pandaan District is enough to meet their daily needs in order to exhibit the importance of Place Dependence (Trabka, 2019).

Based on the explanation above, it is shown that changes in land use arise due to changes in social, economic, and environmental conditions. The status of the population often changes along with the change in land use, where there is a connection between the population's social status and the change in land use. The population dependency that affects the social conditions of the population towards change can be explained through the place dependence of the people of the Pandaan District (Verburg et al., 2015). Based on this description, the research is required to analyze the relationship between Place Dependence and land-use change in the Pandaan District of Pasuruan Regency in relation to sustainable agriculture.

\section{RESEARCH METHOD}

This study was carried out in the Pandaan District of Pasuruan Regency for five months from June to October 2020. The data were collected from primary sample using such instruments as observation, interviews, and questionnaires to respondents. There were 500 respondents of undeveloped landowners, both farmers and non-farmers. A secondary survey was also performed to find data from relevant agencies.

Several analyses were conducted. They were analyses on the change in land use in relation to time series land overlay and place dependence, the relevant variables, and the relation of land dependency to change in land use.

Land-use change or spatial analysis in time series overlays is derived from satellite image digitalization vector data as raster data (Figure 1). The raster data used are satellite image data in the base year of 2010 and the new land use in 2020. Year 2010 was used as the base year since the Malang-Pandaan toll road was not yet constructed in that year. In 2020, the year of current land use, there were already several changes in land use or land transfer in the area being used for the construction of a toll road crossing the Pandaan District from Surabaya to Malang. 


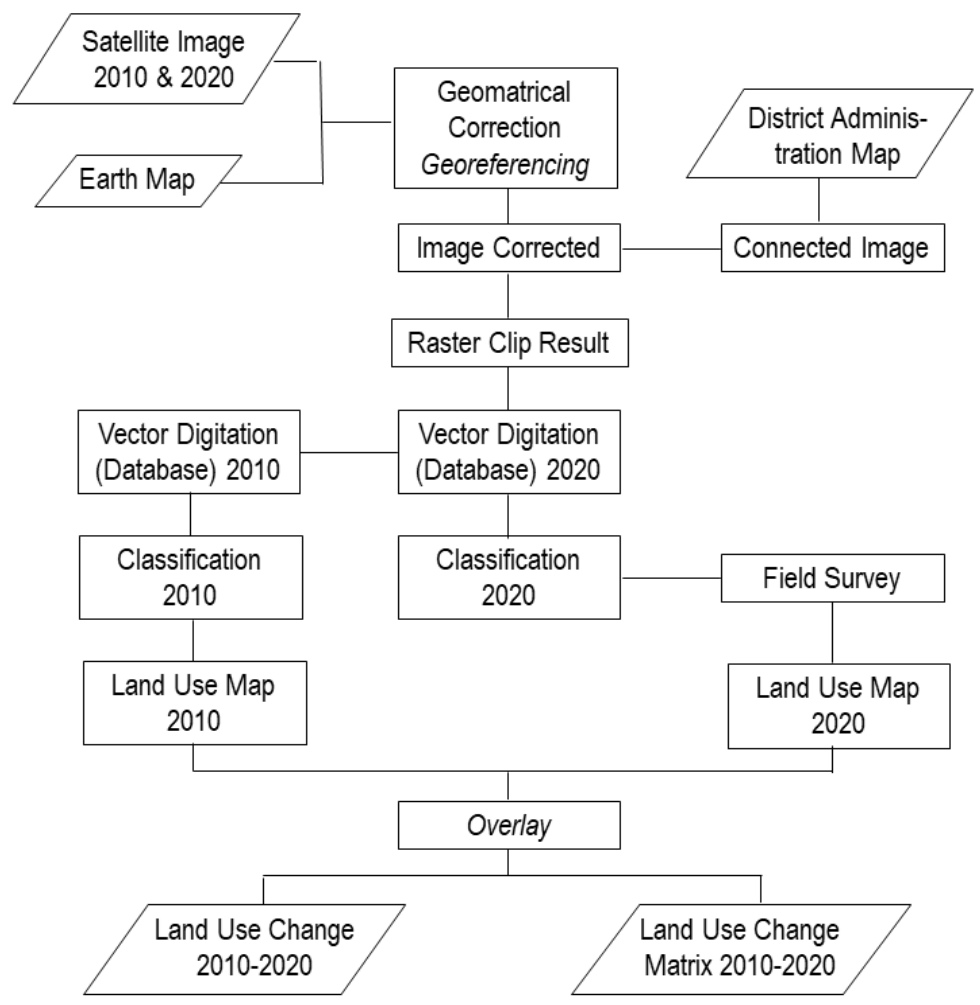

Figure 1. The Flow of land-use change analysis

The spatial analysis used a descriptive procedure, which generated a transition matrix for land-use change. Descriptive approach was used to explain the results of the interpreted data set. Description or clarification of the effects of spatial analysis is known as a spatial descriptive, and the product of measurement is called the quantitative descriptive transition matrix. In this research, the spatial analysis utilized the Geographic Information Systems (GIS) tool, namely Google Earth Pro and Arcmap 10.5. The steps for spatial analysis (overlay) of changes in land use were (i) the compilation of satellite imagery data during the period of 2010-2018 to ensure the visibility of differences and growth of the MalangPandaan road network; (ii) the translation of satellite imagery into a vector file of land use (built / not built) using the ArcMap program (i.e. ArcMap 10.5 version); (iii) the spatial analysis process to connect the interpretations showing shifts in land use, followed by the extension image analysis using the 2010 and 2020 images. The findings of perception differed or overlapped. The effects of differences in land use trends were entered into a 2010-2018 matrix or land-use transition chart.

The place dependency analysis $(X)$ used the part of the place attachment index analysis. Place dependency analysis used the descriptive analysis techniques to conclude with the mode value. The survey used a Likert scale of 33 statements based on five variables. The variables included land ownership $(X 1)$, the quality of the environment (X2), income (X3), accessibility (X4), and career development(X5) (Table 1). A questionnaire was given to respondents living in the Pandaan District to analyze the place dependence measurement $(X)$, as Salimah mentioned (2018).

Questionnaire data to assess position dependence $(\mathrm{X})$ were in the form of data on place dependence $(\mathrm{x})$ for names, jobs, addresses, and 10 other statements. The items were distributed into nine statements regarding land ownership (X1), six statements about environmental quality $(X 2)$, five statements on income (X3), eight statements about accessibility (X4), and five statements on career (X5). 
Table 1. Variables Used in the Model

\begin{tabular}{|c|c|c|}
\hline Endogenous Variables & Exogenous Variables & Source \\
\hline \multirow[t]{8}{*}{ Place Dependence } & Place of origin & Trabka (2019) \\
\hline & Length of stay & Trabka (2019) \\
\hline & Land ownership & Baldwin et al. (2017); Aulia (2019); \\
\hline & Environmental Quality & Haryani (2019); Lai et al. 2012; \\
\hline & Income & Aulia (2019); Trabka (2019); \\
\hline & Accessibility & Haryani (2019); Trabka (2019) \\
\hline & Career Development & $\begin{array}{l}\text { (Lai \& Kreuter, } 2012 ; \text { Suroso et al., 2014; Trabka, } \\
\text { 2019) and adapted from Hadidya et al. (2018) }\end{array}$ \\
\hline & Attitude to protect the land & Lokocz, Ryan, \& Sadler, 2011 \\
\hline $\begin{array}{l}\text { Attitudes towards land } \\
\text { development }\end{array}$ & & Adapted from Aulia (2019) \\
\hline The decision to sell land & & (Prayitno et al., 2018) \\
\hline
\end{tabular}

The items were divided into five answer levels, from "strongly agreed" (equal to 5 points) for the most positive response to "strongly disagree" = (equal to 1 point) for the most negative answer. The evaluation of the respondent was given to the 33 statements.

The relationship between place dependence and land-use transition was found using the Partial Least Square (PLS) analysis using the Smart-PLS 3.2 program. The PLS technology based on Hartanto (2018) explicitly evaluated latent variables, indicator variables, and measurement errors. The unobserved variables representing a latent variable were calculated based on the content of the analysis. In this research, the partial least square analysis aims to assess the relationship between change in land use and place dependence. The degree of latent variables consists of latent high-order variables that affect a single degree and latent first-order variables affecting the observed variables.

\section{RESULT AND DISCUSSION}

\section{Respondent Characteristics}

The distribution of 500 respondents with productive age of 15 to 65 years is $98.4 \%$. Based on their primary occupations, it is estimated that 68 percent of the respondents work in agriculture, and the remaining 32 percent work in the non-agriculture sector (Table 2). In addition to the primary employment, there are secondary occupations done by the respondents, with the proportion of being farmers up to $30 \%$, and being non-farmer workers as many as $70 \%$, (e.g. laborers and village officials).
The income of the respondents is classified into primary and secondary income. As many as 47 percent of the respondents mentioned that their main range of revenue was 1 million to 2 million rupiahs, while 68 percent said that their secondary revenue accounts had a nominal value of less than 1 million rupiahs. As for the length of stay, it is known that 47.6 percent of the population have lived for 4150 years in the Pandaan District.

Forty-four percent of respondents live within a 400-600 m distance from the land, and 68 percent of the land possessed by 68 percent of interviewees having an area of 0.5-29 ha. They dominate the domestic distance, affecting the production and productivity of farmers.

\section{Change of Land Function}

In the last ten years (2010-2020), land use in Pandaan district has changed. The maps showing change of the land use in 2010 and 2020 in Pandaan District are shown in Figure 2. In almost all villages in Pandaan District, there are more residential areas and land-use changes due to the toll road's development. Figure 2 indicates that many villages and districts, including Wedoro Village and Karangjati Village, already have highways and toll roads in the center of Pandaan. The southern part of the toll road passes through the central part of the Pandaan District through Kutorejo district and Jogosari district. The northern section of the road is Nogosari Village and Kebonwaris Village. 

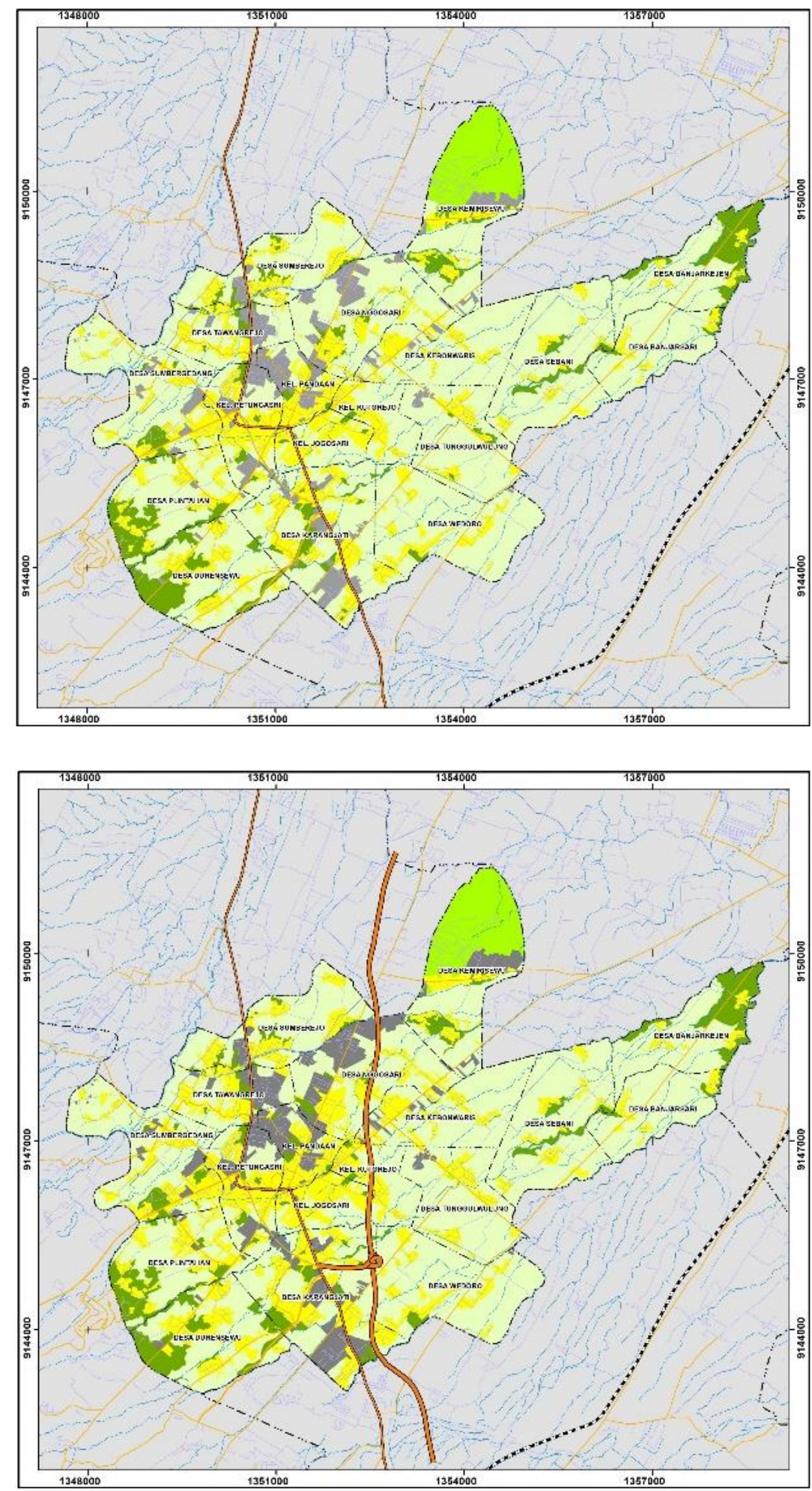

Figure 2. Land use map of Pandaan District, 2010 (top) and 2020 (bottom) 
Table 2. Characteristics of Respondent in Pandaan District

\begin{tabular}{|c|c|c|}
\hline Variable & Percentage & $\begin{array}{c}\text { Number of } \\
\text { people }\end{array}$ \\
\hline & $\%$ & \\
\hline \multicolumn{3}{|l|}{ Primary occupation } \\
\hline - agriculture & 68.0 & 342 \\
\hline - non-agriculture & 32.0 & 158 \\
\hline \multicolumn{3}{|l|}{ Side Job } \\
\hline - farmer & 30.0 & 152 \\
\hline - non-farmer & 70.0 & 348 \\
\hline \multicolumn{3}{|l|}{ Income per month } \\
\hline$<1.0$ million rp & 4.0 & 21 \\
\hline $1.0-2.0$ million rp & 47.0 & 234 \\
\hline $2.0-3.0$ million rp & 28.0 & 139 \\
\hline $3.0-4.0$ million rp & 16.0 & 79 \\
\hline$>4.0$ million rp & 5.0 & 27 \\
\hline \multicolumn{3}{|l|}{ Length of stay } \\
\hline 10 - 16 years & 1.2 & 6 \\
\hline $17-23$ years & 0.1 & 1 \\
\hline 24 - 30 years & 2.8 & 14 \\
\hline 31 - 37 years & 11.2 & 56 \\
\hline $38-44$ years & 26.2 & 131 \\
\hline 45 - 51 years & 30.0 & 150 \\
\hline $52-58$ years & 19.2 & 96 \\
\hline 59 - 65 years & 8.2 & 41 \\
\hline $66-72$ years & 0.6 & 3 \\
\hline 73 - 79 years & 0.0 & 0 \\
\hline 79 - 85 years & 0.4 & 2 \\
\hline \multicolumn{3}{|l|}{ Distance to the land } \\
\hline $10-210 m$ & 26.8 & 134 \\
\hline $220-420 m$ & 28.2 & 141 \\
\hline $430-630 m$ & 32.6 & 163 \\
\hline $640-840 m$ & 3.0 & 15 \\
\hline $850-1050 m$ & 5.2 & 26 \\
\hline $1060-1260 m$ & 0.0 & 0 \\
\hline $1270-1470 m$ & 0.6 & 3 \\
\hline $1480-1680 m$ & 1.0 & 5 \\
\hline $1690-1890 m$ & 0.0 & 0 \\
\hline $1900-2100 m$ & 2.6 & 13 \\
\hline \multicolumn{3}{|l|}{ Land size } \\
\hline $0.1-0.59$ ha & 47.4 & 237 \\
\hline $0.6-1.09$ ha & 30.2 & 151 \\
\hline $1.1-1.59$ ha & 5.4 & 27 \\
\hline $1.6-2.09 \mathrm{ha}$ & 8.2 & 41 \\
\hline $2.1-2.59$ ha & 0.2 & 1 \\
\hline $2.6-3.09$ ha & 2.4 & 12 \\
\hline $3.1-3.59$ ha & 0.0 & 0 \\
\hline $3.6-4.09$ ha & 3.2 & 16 \\
\hline $4.1-4.59$ ha & 0.0 & 0 \\
\hline $4.6-5.09$ ha & 3.0 & 15 \\
\hline
\end{tabular}

Table 3 and Table 4 present land-use change data from 2010 to 2020, divided into five dominant land use categories in the Pandaan District. In general, land conversion from wetland agricultural areas in the form of ricefields into residential areas in all villages/wards of the district of Pandaan amounts to 213.69 ha.

\section{Place Dependence}

Place Dependence of the Pandaan District was evaluated through respondents' assessments of Pandaan District capacity statements to achieve population objectives, including residence ownership, environmental quality, needs-friendly income, accessibility, and career development.

Table 3. Land Use Area of Pandaan District in 2010 and 2020

\begin{tabular}{lrrrr}
\hline Land Use & 2010 & 2020 & \multicolumn{2}{c}{$\begin{array}{c}\text { Change in } \\
\text { Area Size }\end{array}$} \\
\hline & $\ldots \ldots \ldots \ldots$ & hectare & $\ldots \ldots \ldots . .$. & $\%$ \\
Industry & 254.0 & 333.9 & 79.9 & 1.834 \\
Settlement & 810.6 & 959.1 & 148.5 & 3.405 \\
Green open space & 166.4 & 165.6 & -0.8 & -0.019 \\
Rice fields/wetlands & 2789.2 & 2568.5 & -220.7 & -5.064 \\
Dryland/moor & 337.8 & 331.0 & -6.8 & -0.156 \\
Total area & 4358.1 & 4358.1 & & \\
\hline
\end{tabular}

Table 4. Land Use Change for Each Village in Pandaan District, 2010-2018

\begin{tabular}{|c|c|c|c|c|c|}
\hline Village & Industry & $\begin{array}{c}\text { Settle- } \\
\text { ment }\end{array}$ & $\begin{array}{l}\text { Green } \\
\text { Open } \\
\text { Space }\end{array}$ & $\begin{array}{l}\text { Paddy } \\
\text { Land }\end{array}$ & $\begin{array}{l}\text { Dry } \\
\text { Land }\end{array}$ \\
\hline & \multicolumn{5}{|c|}{$\ldots \ldots \ldots \ldots \ldots \ldots \ldots \ldots$ hectare } \\
\hline Banjarkejen & 0.27 & 4.67 & 0.00 & -2.26 & -2.69 \\
\hline Banjarsari & 0.00 & 0.76 & 0.00 & -1.22 & 0.45 \\
\hline Durensewu & 1.20 & 15.15 & 0.00 & -16.94 & 0.59 \\
\hline Karangjati & 23.90 & 19.22 & 0.00 & -44.99 & 1.88 \\
\hline Kebonwaris & 2.06 & 5.48 & 0.00 & -7.53 & 0.00 \\
\hline Kemirisewu & 4.83 & 6.75 & -1.03 & -4.92 & -5.63 \\
\hline Nogosari & 28.38 & 14. & 0.00 & -41 & -0.81 \\
\hline Plintahan & 0.00 & 13.27 & 0.00 & -11.08 & -2.19 \\
\hline Sebani & 0.00 & 5.67 & 0.00 & -5.67 & 0.00 \\
\hline Sumberejo & 0.13 & 4.46 & 0.00 & -0.99 & -3.59 \\
\hline Sumbergedang & 0.00 & 15.30 & 0.00 & -18.12 & 2.82 \\
\hline Tawangrejo & 9.12 & 8.79 & 0.00 & -17.94 & 0.04 \\
\hline Tunggulwulung & 0.21 & 7.08 & 0.59 & -3.42 & -4.46 \\
\hline Wedoro & 0.08 & 6.76 & 0.00 & -8.94 & 2.11 \\
\hline Jogosari & 0.15 & 11.33 & 0.00 & -11.48 & 0.00 \\
\hline Kutorejo & 0.00 & 2.73 & 0.00 & -4.56 & 1.83 \\
\hline Pandaan & 4.84 & 1.25 & 0.00 & -8.43 & 2.34 \\
\hline Petungasri & 0.78 & 1.82 & 0.00 & -3.54 & 0.94 \\
\hline Total Ärea & 75.93 & 144.56 & -0.44 & -213.69 & -6.37 \\
\hline
\end{tabular}

Based on the comments made by respondents on the Likert scale questionnaire, the population agreed that they have adequate workload in their occupations; the average working time is 8 hours. They also felt comfortable with their access to the workplaces. The happiness of the people of Pandaan District was linked with where they live.

Pandaan District's people accepted that the quality of the area where they live is good, although some people believed there is a lack of 
environmental quality. The majority of the population decided that the environmental quality was fine, so the population was linked to their place dependence.

Residents believed that their income is adequate to satisfy human physiological needs. The revenues of 1 to 2 million rupiahs per month were considered enough by the majority of people. This means that the residents of Pandaan District are not pressured from the financial point of view. Earnings that can satisfy their needs are connected with their residence.

The results of the analysis indicate that access to the place is easy and inexpensive for the community. People enter these locations using their private vehicles, including cars and motorcycles. Costs are paid for transportation costs to access these locations. The fuel expense of people is 45 to 100 thousand rupiahs on average. The realization of these factors gives the population an impression of where they live.

The people accept that the workload of their occupation is adequate, with the average working time as long as 8 hours. People also feel comfortable with the access to their workplaces. The sense of satisfaction of Pandaan District people displays a connection to where they live.

\section{Relationship between Place Dependence and Shift of Land Functions}

The assessment of measuring the outer model is done to define the validity and reliability of the model in loading value (see Appendix). The converging and unequal validity of the manifest variables forming latent variables, as well as the composite reliability and alpha Cronbach were evaluated (Ghozali \& Hengky, 2015). The loading factor value of each research indicator indicates that all latent variables are discriminatory and reliable (Table 5). The AVE value for each variable reaches the value limit of 0.5 . The variables in this analysis are accurate, and the indicators are suited to measuring the build or latent variable.

Based on the reliability test results, the value of Cronbach alpha and composite reliability exceeds the minimum limit of 0.7 , respectively. All indicators identified by the researcher are reliable when the latent variables are clarified.

The assessment of a structural model or an assessment of the inner model attempts to predict the relationship between latent variables (Ghozali \&
Hengky, 2015). The latent variables concerning the relationship are place dependence, construction attitude, and the decision to change property. The relation among these latent variables is seen when the R-square, path, and indirect effect are tested.

Table 5. Reliability and Validity of Research Variables

\begin{tabular}{lccc}
\hline Variable & $\begin{array}{c}\text { Cronbach } \\
\text { Alpha }\end{array}$ & $\begin{array}{c}\text { Composite } \\
\text { Reliability }\end{array}$ & $\begin{array}{c}\text { Average } \\
\text { Variance } \\
\text { Extracted }\end{array}$ \\
\hline Accessibility & 0.861 & 0.891 & 0.508 \\
Place of origin & 1.000 & 1.000 & 1.000 \\
Residence ownership & 0.878 & 0.903 & 0.509 \\
Decision to change land & 1.000 & 1.000 & 1.000 \\
Environmental quality & 0.814 & 0.866 & 0.520 \\
Length of stay & 1.000 & 1.000 & 1.000 \\
Career development & 0.864 & 0.902 & 0.649 \\
Income that meets needs & 0.897 & 0.924 & 0.707 \\
Attitudes towards land & 0.807 & 0.862 & 0.517 \\
$\quad$ development & & & \\
\hline
\end{tabular}

The R-square values (Table 6) for each endogenous (latent) variable of place dependence is 0.994 or 99.4 percent. This indicates that the latent variables used for calculating the place dependence value (duration of stay, place of origin, consideration of land choice, environmental quality, income to meet needs, accessibility, and the creation of careers) are high. Meanwhile, the endogenous variables of land transition and land-building attitudes have R-square values of 0.37 or $37 \%$ and 0.123 or $12.3 \%$, respectively, and are categorized as weak.

Table 6. R-Square Value of Endogen Variables

\begin{tabular}{lc}
\hline Latent Variable & R-square \\
\hline Place dependence & 0.994 \\
Attitude toward development & 0.123 \\
Decision to change the land & 0.037 \\
\hline
\end{tabular}

Two coefficients are used in the discussion of the relation: path coefficient and effect size. The path coefficient is used to see the form of relation and how each factor contributes to the place dependence. The impact size (IS) then explores the effect degree of each variable in relation to the place dependence. Kock (2015) noted that the IS is very weak (less than 0.02), the IS is weak (less than 0.02$0.15)$, the IS is moderate $(0.16-0.35)$, the IS value is high. Table 7 describes the connection between each variable and place dependence.

The latent variable of the length stay has a direct relationship to the place dependence. Creating 
functional attachments takes time, but not much because it is easy (Trabka, 2019). The relationship between variables is negative, which means if the population stays longer, it decreases its commitment to Pandaan District. The majority of respondents have spent $45-51$ years in the Pandaan District. This should be noted as the length of stay in the Pandaan District has a mild impact on place dependence.

Table 7. Estimate Variable Affecting Place Dependence

\begin{tabular}{lcc}
\hline Variable & $\begin{array}{c}\text { Path } \\
\text { Coefficient }\end{array}$ & Impact size \\
\hline Accessbillity & 0.211 & 0.020 \\
Place of origin & 0.177 & 0.014 \\
Residence ownership & 0.091 & 0.010 \\
Enviromental quality & 0.787 & 0.040 \\
Length of stay & -0.165 & 0.016 \\
Income & -0.051 & 0.011 \\
Career development & 0.231 & 0.030 \\
\hline
\end{tabular}

The income variable is directly linked to place dependence. Getting an income enough to live in a position would give a feeling of tension or a sense of comfort (Sina, 2012; Trabka, 2019). The relationship between these two variables is negative, which means if the population's income continues to rise, it will reduce the place dependence in Pandaan District more than required. The majority of respondents' revenue is as many as 1.0 to 2.0 million rupiahs, which they say is sufficient for standard requirements, although their income has a poor place-dependent relationship in Pandaan District.

Meanwhile, the latent variable of accessibility has a clear relationship with place dependence. Hummon in Haryani et al. (2019) and Trąbka (2019) clarified that having easy and inexpensive access to the locations will give the people a sense of comfort. The relationship between these two variables has a lively character. If the population feels relaxed accessing locations (public facilities, nature, workplaces, and hobbies), the importance of the population's location dependence on the Pandaan District will increase. Respondents find it convenient to access these places. After all, they have private vehicles, such as cars and motorbikes, to provide comfort and make travel costs more effective because they use selfpurchased fuel for personal use. The average cost of fuel is between 45 thousand and 100 thousand rupiahs. Accessibility has a mild relationship to affect place dependence in the Pandaan District.
The latent variable of origin has a direct relationship to the place dependence. Whether their new residence far away or close to its area of origin is not a problem for the people because they believe they suit their requirements (Trabka, 2019). The relationship between these two variables has a dynamic character, meaning that people who have lived and were born in the Pandaan District are more reliant. As many as $94 \%$ of respondents are people who were born and are residing in Pandaan District.

The latent variable of residence ownership has a direct relationship to dependence on location. Property ownership can provide a sense of comfort following the needs of the population that causes dependence (Baldwin et al., 2017; Sina, 2012). The relation between these two variables is excellent so that a place to live that can still respond to the population's requirements and provide a high degree of dependence.

Environmental quality variables are directly linked to place dependence. Hummon in Haryani et al. (2019) and Lai \& Kreuter (2012) demonstrated that having a fair environmental assessment of the people would offer a feeling of comfort and lead to place dependence.

Trabka (2019) explained that fulfilling work is accomplished through a workload that keeps with one's skills and that provides comfort to keep them engaged.

Career development is also correlated with place dependence. The relationship between the two variables is positive and able to increase the reliance on the place if the career development is more satisfactory. The majority of respondents agreed that they are happy with their jobs. The career development is significant because the impact of the Pandaan District people on place dependence is classified as moderate.

Table 8. Coefficient Relationship with Decision to Change Land

\begin{tabular}{lccccc}
\hline & & \multicolumn{2}{c}{ Direct } & \multicolumn{2}{c}{ Indirect } \\
Variable & $\begin{array}{c}\text { Size } \\
\text { Effect }\end{array}$ & \multicolumn{2}{c}{ relationship } & relationship \\
\cline { 3 - 6 } & & $\mathrm{t}$ & $\mathrm{p}$ & $\mathrm{t}$ & $\mathrm{p}$ \\
value & value & value & value \\
\hline $\begin{array}{l}\text { Place } \\
\text { dependence }\end{array}$ & 0.10 & 0.464 & 0.185 & 3.182 & 0.002 \\
\hline
\end{tabular}




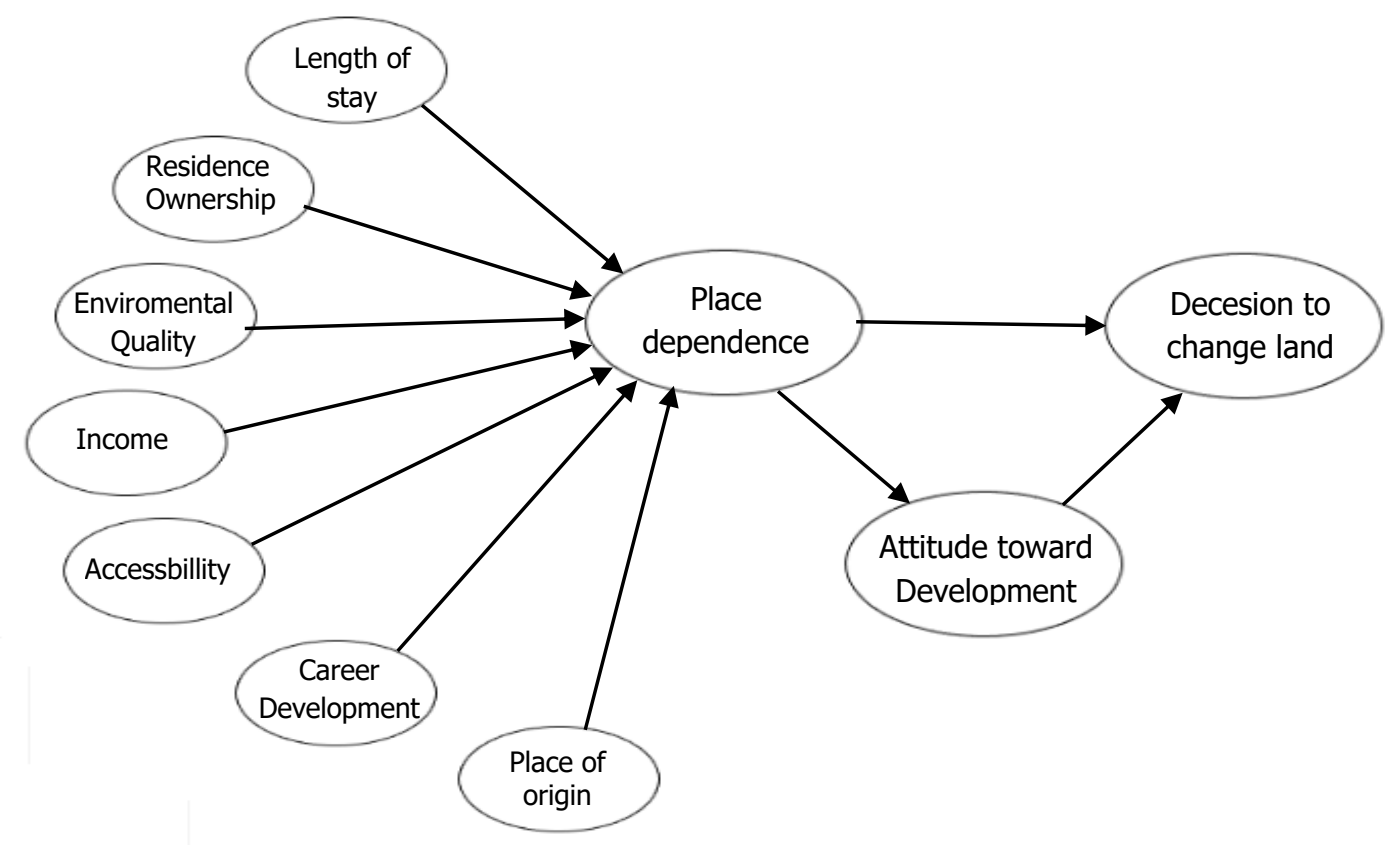

Figure 3. Relationship (total effect) of place dependence and land change decisions

Furthermore, this research shows direct and indirect relationships between place dependence and land-use change. The place dependence has an indirect relationship to the population's decision to change the land (Table 8). This relationship shows the role of mediator variable of the population's attitude towards growth. The mediator variable is a variable that affects the values of the interrelated endogenous variables and exogenous variables ( $\underline{\text { Hair }}$ et al., 2014). The study results show that the higher the population's place dependence in the district of Pandaan, the more community continues to avoid physical changes in their environment so that the population makes a decision not to alter their own.

Besides, the indirect relationship of place dependence between people and land use changes is affected significantly by environmental quality (Table 8 and Figure 3). This illustrates how vital the ecosystem where people live is to be preserved. Environmental factors that sustain their quality are the conservation of harmonious neighborly relations, healthy neighborhoods, preservation of dense houses in the environment, maintenance of infrastructural conditions, the state of residential facilities, and health facilities. That is significant because it reduces the population's decision to change land and reduces the magnitude of the action of land conversion in Pandaan District.

Table 9. Total Effect of Place Dependence on Decision to Change The Land

\begin{tabular}{lrcc}
\hline Variable & $\begin{array}{r}\text { Total } \\
\text { Effect }\end{array}$ & t value & p value \\
\hline Accessbillity & 0.024 & 0.092 & 0.143 \\
Place of origin & 0.020 & 1.202 & 0.105 \\
Residence Ownership & 0.100 & 0.890 & 0.309 \\
Enviromental Quality & 0.090 & 2.128 & 0.006 \\
Length of stay & -0.019 & 1.100 & 0.125 \\
Income & -0.006 & 0.581 & 0.383 \\
Career Development & 0.026 & 0.839 & 0.085 \\
\hline
\end{tabular}

Based on the path analysis, social factors (place dependence) are related to the community's decision to transfer land functions (Table 9). The total effect of length of stay $(-0.019)$ and income $(-0.006)$ are negative, meaning that the longer they stay and the greater the income, the lower the decision to change the land function. Whereas, place dependence will affect attitudes towards development, which will also affect the decision to transfer land functions.

The decision to change the land function demonstrates changes in people's attitudes about 
land development. The respondents' decision to change land function is also the last statement regarding efforts to conserve its uncultivated land or the outcome of that land. Respondents answered either "Yes" or "No" to the query of whether respondents would change the land function. The results of the survey revealed that $69 \%$ of respondents do not intend to make land improvements and $31 \%$ intend to do so.

\section{Research Implication}

Surveys from urban areas, such as the villages of Pandaan, Kutorejo, Jogosari, and Petungasri, indicate that their people favor changing their land function. The majority of the city area has been developed, and there is good access to surrounding areas. People in the villages believe that building trade/service centers in previously undeveloped regions is more profitable than developing agricultural areas. Meanwhile, in rural areas, most people said they would not alter their land use pattern. However, some villages, such as Sumberejo, Nogosari, Kemirisewu, Plintah, and Kebonwaris, have a higher percentage of people that favor "yes" votes than the neighboring villages.

Based on the path chart analysis, it is known that there is a negative relationship between the length of stay and income. This means that the length of stay affects the decision to change the functions of the land. The longer the people live in the village, they will tend to decide not to change the functions of the land. Meanwhile, the higher the income from the agricultural sector that is being cultivated, it will reduce the population's decision to change the function of the land. The decision to change the land is the response of the people to the developments in Pandaan District. The development of Pandaan District will cause a physical change in the region. This change is then interpreted economically by the population as an opportunity to make a greater profit (Lokocz et al., 2011)

Based on this research, the government must pay attention to the structure of the community in terms of land tenure where the longer the population lives, the lower the decision to change land functions. How to increase people's income from the agricultural sector is another challenge. Input subsidies (fertilizers, medicines, agricultural equipment), as well as infrastructure improvements of roads and irrigation, can be applied to increase farmers' incomes to reduce the decision to change land functions. If it is possible to decide to change the function of the land, it will facilitate the implementation of sustainable agriculture.

\section{CONCLUSION AND SUGGESTION}

The land-use transition took place in Pandaan District, as shown by land-use changes. Changes in land use and significant changes in the area arise in wetlands or rice fields. While the area is shifting, $69 \%$ of respondents still want to defend their territories. The respondents wish to retain their current environment because the current landscape supports people's activities. The main activity of people in Pandaan District is agriculture, so their people do not want to repurpose their land.

The people of Pandaan District feel attached to their home. The respondents thought that their hope of living and working comfortably in the Pandaan District is fulfilled. The factor that has a significant effect on the population's place dependence is environmental quality. In general, Pandaan's environmental conditions are decent and have satisfied people with a sense of comfort.

Dependence on locations and land-use changes in the district of Pandaan are closely related. They have indirect and constructive relations. The more people are attached to their homes, the more they want to preserve the same landscape conditions to ensure that they do not alter their land. Moreover, because of environmental quality, the relationship between place dependence and land conversion decisions arises. Good environmental conditions will provide people with a feeling of security that will contribute to the place attachment so that people make decisions to change the land.

The findings of this study are the basis for the development of regulatory tools to promote sustainable agriculture. Sustainable agricultural land policies can help safeguarding the subsidies provision for agricultural inputs as well as improving agricultural infrastructure (roads, irrigation) to increase farmers' incomes, which then can reduce the decision to change land functions. In the meantime, the length of stay related to the sustainability of land tenure by future generations (farmers' descendants) also needs to be considered. A good environment that can provide sufficient 
income will encourage people to protect the land, which in turn will support sustainable agriculture.

\section{ACKNOWLEDGMENT}

The Author would like to thanks the Research Board and Community Service of the Engineering Faculty (BPPM FT UB) of Brawijaya Malang University for supporting research work on Doctoral grants.

\section{REFERENCES}

Anton, C. E., \& Lawrence, C. (2016). The relationship between place attachment, the theory of planned behaviour and residents' response to place change. Journal of Environmental Psychology, 47 145-154.

https://doi.org/10.1016/j.jenvp.2016.05.010

Aulia, F. (2020). Land-use shifting from settlement into commercial in Caturtunggal, Sleman. JEJAK: Jurnal Ekonomi dan Kebijakan, 13(1), 1-16. https://doi.org/10.15294/jejak.v13i1.19598

Baldwin, C., Smith, T., \& Jacobson, C. (2017). Love of the land: Social-ecological connectivity of rura landholders. Journal of Rural Studies, 51, 37-52. https://doi.org/10.1016/j.jrurstud.2017.01.012

Bappeda Kabupaten Pasuruan. (2010). Rencana Tata Ruang Wilayah Kabupaten Pasuruan 2010-2030.

Boron, V., Payán, E., MacMillan, D., \& J. Tzanopoulos. (2016). Achieving sustainable development in rural areas in Colombia: Future scenarios for biodiversity conservation under land use change. Land Use Policy, 59, 27-37. https://doi.org/doi.org/10.1016/j.landusepol.2016 .08 .017

BPS. (2020). Kecamatan Pandaan dalam Angka 2015. Badan Pusat Statistika Kabupaten Pasuruan, Provinsi Jawa Timur. Retrieved from https://pasuruankab.bps.go.id/publication.html?p age $=3$

Foley, J. A., Defries, R., Asner, G. P., Barford, C., Bonan, G., Carpenter, S. R., \& Snyder, P. K. (2005). Global consequences of land use Science. Science, 309(5734), 570-574. https://doi.org/10.1126/science.1111772

Ghozali, I., \& Hengky, L. (2015). Konsep, Teknik Dan Aplikasi Menggunakan Program Smart PLS 3.0. In Universitas Diponegoro. Semarang https://openlibrary.telkomuniversity.ac.id/pustaka /117046/partial-least-squares-konsep-teknik-danaplikasi-menggunakan-program-smartpls-3-0-2-e.html
Hadidya, S., Rahmawan, \& Susatyo, Y. S. (2018) Hubungan antara Persepsi Beban Kerja dengan Kepuasan Kerja Karyawan [Universitas Muhammadiyah Surakarta]. http://eprints.ums.ac.id/64405/

Hair, J. F., Sarstedt, M., Hopkins, L., \& Kuppelwieser, V. G. (2014). Partial least squares structural equation modeling (PLS-SEM): An emerging tool in business research. European Business Review, 26(2), 106-121. https://doi.org/10.1108/EBR-102013-0128

Hartanto. (2018). Pengaruh kinerja keuangan terhadap harga saham bank umum swasta nasional yang terdaftar di Bursa Efek Indonesia. Journal of Business Studies, 3(4), 45-57. http://journal.uta45jakarta.ac.id/index.php/jbsuta /article/view/1200/816

Haryani, E., Rukmi, W. I., \& Setyono, D. A. (2019). Hubungan place attachment dengan partisipasi masyarakat dalam Program PLPBK di RW 04 Kelurahan Polehan. Jurnal Tata Kota Dan Daerah, 11(1), 1-10. https://doi.org/10.21776/ ub.takoda.2019.011.01.1

Kock, N. (2015). Common method bias in PLS-SEM: A full collinearity assessment approach. International Journal of E-Collaboration, 11(4), 110. https://doi.org/10.4018/ijec.2015100101

Lai, P. H., \& Kreuter, U. P. (2012). Examining the direct and indirect effects of environmental change and place attachment on land management decisions in the Hill Country of Texas, USA. Landscape and Urban Planning, 104(3-4), 320-328. https://doi.org/doi.org/ 10.1016/j.landurbplan.2011.11.007

Lambin, E. F., \& Meyfroidt, P. (2010). Land use transitions: Socio-ecological feedback versus socio-economic change. Land Use Policy, 27(2), 108-118. https://doi.org/doi.org/10.1016/ j.landusepol.2009.09.003

Lokocz, E., Ryan, R. L., \& Sadler, A. J. (2011). Motivations for land protection and stewardship: Exploring place attachment and rural landscape character in Massachusetts. Landscape and Urban Planning, 99(2), 65-76. https://doi.org/10.1016/ j.landurbplan.2010.08.015

Long, H., \& Qu, Y. (2018). Land use transitions and land management: A mutual feedback perspective. Land Use Policy, 74, 111-120. https://doi.org/doi.org/10.1016/j.landusepol.2017 .03 .021

Nugraha, A. T., Prayitno, G., Situmorang, M. E., \& Nasution, A. (2020). The role of infrastructure on 
economic growth and income inequality of Indonesian. Economics and Sociology, 13(1), 102-115. https://doi.org/10.14254/2071

Prayitno, G., Dinanti, D., Rusmi, S. A., Surjono, \& Dwi Maulidatuz, Z. (2019). Place attachment index of landowners in Pandaan Sub-District, Pasuruan Regency, Indonesia. IOP Conference Series: Earth and Environmental Science. https://doi.org/10.1088/1755-1315/239/1/012045

Prayitno, G., Sari, N., Hasyim, A. W., \& Nyoman, S. W. (2020). Land-use prediction in Pandaan District Pasuruan Regency. International Journal of Geomate, 18(65), 64-71. https://doi.org/10.21660/2020.65.41738

Prayitno, G., Surjono, Hidayat, A. R. T., Subagiyo, A., \& Paramasasi, N. K. (2018). Factors that effect to land use change in Pandaan District. IOP Conference Series: Earth and Environmental Science, 202(1). https://doi.org/10.1088/1755$1315 / 202 / 1 / 012006$

Purnomo, P., Oktaviani, A. I., \& Nugroho, I. (2018). The sacred site: The conservation based on the local people in tengger community and its potential as ecotourism activities. Journal of Socioeconomics and Development, 1(1), 7-15. https://doi.org/10.31328/jsed.v1i1.517

Romagosa, C. M., Morse, W. C., \& Lockaby, B. G. (2013). Emerging issues along urban-rural interfaces: an introduction to the special issue. Urban Ecosystems, 16(1), 1-2. https://doi.org/10.1007/s11252-013-0299-y

Rusmi, S. A. (2019). Keterkaitan Place Attachment terhadap Keputusan Mengubah Lahan di Kecamatan Pandaan. Universitas Brawijaya.

Siciliano, G. (2012). Urbanization strategies, rural development and land use changes in China: A multiple-level integrated assessment. Land Use Policy, 29(1), 165-178. https://doi.org/10.1016/ j.landusepol.2011.06.003

Sina, P. G. (2012). Analisis stres finansial pada gender. Jurnal Ekonomi \& Pendidikan, 9(1), 102112. https://journal.uny.ac.id/index.php/jep/ article/view/4157/3600
Sina, P. G., \& Raturomon, L. T. (2015). Analisis stres finansial pada gender. Jurnal Ekonomi Dan Pendidikan. https://doi.org/10.21831/jep.v9i1.4157

Suroso, H., Hakim, A., \& Noor, I. (2014). Faktorfaktor yang mempengaruhi partisipasi masyarakat dalam perencanaan pembangunan di Desa Banjaran Kecamatan Driyorejo Kabupaten Gresik. Wacana Journal of Social and Humanity Studies, 17(1), 7-15. https://wacana.ub.ac.id/ index.php/wacana/article/view/290

Trąbka, A. (2019). From functional bonds to place identity: Place attachment of Polish migrants living in London and Oslo. Journal of Environmental Psychology, 62, 67-73. https://doi.org/10.1016/j.jenvp.2019.02.010

Verburg, P. H., Crossman, N., Ellis, E. C., Heinimann, A., Hostert, P., Mertz, O., Nagendra, H., Sikor, T., Erb, K. H., Golubiewski, N., Grau, R., Grove, M., Konaté, S., Meyfroidt, P., Parker, D. C., Chowdhury, R. R., Shibata, H., Thomson, A., \& Zhen, L. (2015). Land system science and sustainable development of the earth system: A global land project perspective. Anthropocene, 12, 29-41. https://doi.org/10.1016/ j.ancene.2015.09.004

Walker, A., \& Ryan, R. . (2008). Place attachment and landscape preservation in rural New England: A Maine case study . Landscape and Urban Planning, 86(2), 141-152. https://doi.org/doi.org/ 10.1016/j.landurbplan.2008.02.001

Wang, J., Lin, Y., Glendinning, A., \& Xu, Y. (2018). Land-use changes and land policies evolution in China's urbanization processes. Land Use Policy, 75, 375-387. https://doi.org/doi.org/ 10.1016/j.landusepol.2018.04.011

Zeho, F. H., Prabowo, A., Estiningtyas, R. A., Mahadiansar, M., \& Sentanu, I. G. E. P. S. (2020). Stakeholder collaboration to support accountability in village fund management and rural development. Journal of Socioeconomics and Development, 3(2), 89-100. https://doi.org/10.31328/jsed.v3i2.1395 
Appendix. Variable and Indicator Used in Model, and Loading Value of Analysis

\begin{tabular}{|c|c|c|c|}
\hline $\begin{array}{l}\text { Endogenous } \\
\text { Variables }\end{array}$ & $\begin{array}{l}\text { Exogenous } \\
\text { Variables }\end{array}$ & Indicator & $\begin{array}{l}\text { Loading } \\
\text { value }\end{array}$ \\
\hline \multirow[t]{35}{*}{ Place Dependence } & $\begin{array}{l}\text { Origin of the } \\
\text { population }\end{array}$ & Origin of resident area (X1) & 1.000 \\
\hline & Length of stay & How many years did the population live in the Pandaan District (X2) & 1.000 \\
\hline & \multirow{9}{*}{$\begin{array}{l}\text { Land ownership } \\
\text { (X3) }\end{array}$} & I chose the land here because my food and drinking needs were met (X31) & 0.641 \\
\hline & & I chose the land here because my clothing needs are met (X32) & 0.755 \\
\hline & & I chose the land here because my rest needs were met (X33) & 0.614 \\
\hline & & I chose the land here because my sexual needs are being met (X34) & 0.709 \\
\hline & & I chose the land here because my security needs were met (X35) & 0.771 \\
\hline & & I chose the land here because my love needs are met $(\mathrm{X} 36)$ & 0.738 \\
\hline & & I chose the land here because they need to be respected was met (X37) & 0.764 \\
\hline & & $\begin{array}{l}\text { I chose the land here because they need to channel my talents and abilities } \\
\text { was met (X38) }\end{array}$ & 0.734 \\
\hline & & $\begin{array}{l}\text { The consideration of choosing a place to live because of my talents and } \\
\text { abilities has been channeled (X39) }\end{array}$ & 0.676 \\
\hline & Environmental & I have good neighbors (X41) & 0.770 \\
\hline & \multirow{5}{*}{ Quality (X4) } & Safety in my neighborhood is good (X42) & 0.690 \\
\hline & & The house population in my neighborhood is not dense (X43) & 0.781 \\
\hline & & The infrastructure in my neighborhood is good (X44) & 0.686 \\
\hline & & Health facilities in my neighborhood are good (X45) & 0.738 \\
\hline & & $\begin{array}{l}\text { I think the neighborhood I live in has health facilities that are not } \\
\text { problematic (X46) }\end{array}$ & 0.651 \\
\hline & \multirow[t]{5}{*}{ Income (X5) } & My income is sufficient to buy my food and drink needs (X51) & 0.825 \\
\hline & & My income is sufficient to buy my clothing needs (X52) & 0.821 \\
\hline & & My income is sufficient to buy my rest needs (X53) & 0.863 \\
\hline & & My income is sufficient to buy my living needs (X54) & 0.840 \\
\hline & & My income is sufficient to buy my sexual needs (X55) & 0.856 \\
\hline & \multirow[t]{8}{*}{ Accessibility (X6) } & I have access to commuting to work (X61) & 0.680 \\
\hline & & I have access to travel to my hobby (X62) & 0.719 \\
\hline & & I have access to travel to natural areas (X63) & 0.565 \\
\hline & & I have access to travel to public facilities (X64) & 0.667 \\
\hline & & Cost of access to affordable workplaces (X65) & 0.734 \\
\hline & & Affordable cost of access to hobbies (X66) & 0.768 \\
\hline & & Affordable cost of access to natural areas (X67) & 0.768 \\
\hline & & Affordable cost of access to public facilities (X68) & 0.773 \\
\hline & \multirow{5}{*}{$\begin{array}{l}\text { Career } \\
\text { Development } \\
\text { (X7) }\end{array}$} & $\begin{array}{l}\text { I feel capable of doing my work assignments to the best of my physical } \\
\text { abilities (X71) }\end{array}$ & 0.730 \\
\hline & & $\begin{array}{l}\text { I feel less depressed because of mental activities to concentrate, detect } \\
\text { problems, and deal with unexpected events while working (X72) }\end{array}$ & 0.804 \\
\hline & & I can do my job according to the target within a particular time (X73) & 0.824 \\
\hline & & In my job, I can solve problems (X74) & 0.833 \\
\hline & & $\begin{array}{l}\text { I am in a position to complete my work assignments within the time } \\
\text { stipulated (X75) }\end{array}$ & 0.833 \\
\hline \multirow{6}{*}{$\begin{array}{l}\text { Attitudes towards } \\
\text { land development }\end{array}$} & \multirow{6}{*}{$\begin{array}{l}\text { Attitude to } \\
\text { protect the land } \\
\text { (Y1) }\end{array}$} & Protect natural resources (Y11) & 0,662 \\
\hline & & Limiting development to open land and agricultural areas (Y12) & 0,816 \\
\hline & & I am setting aside land for public recreation (Y13) & 0,825 \\
\hline & & Maintain urban service costs for new developments (Y14) & 0,793 \\
\hline & & $\begin{array}{l}\text { Maintain the development of low-density settlements in areas outside urban } \\
\text { areas (Y15) }\end{array}$ & 0,632 \\
\hline & & Keep the majority of development close to urban areas (Y16) & 0,534 \\
\hline $\begin{array}{l}\text { The decision to sell } \\
\text { land }\end{array}$ & & I am willing to sell part or all of my land $(\mathrm{Y} 2)$ & 1.000 \\
\hline
\end{tabular}

